\title{
ATIKAMEKW AND EURO-CANADIAN TERRITORIALITIES AROUND THE SAINT-MAURICE RIVER (1850-1930)
}

In the first decades of the twenty-first century, the inundated traditional territory of the Atikamekw people resurfaced twice, some ninety years after the construction of a reservoir dam on the Upper Saint-Maurice River in Quebec. ${ }^{1}$ In 2007, erosion of the banks of the Gouin Reservoir exposed remains of the Kikendatch cemetery (Mercier 2007). Then, in 2016, the Specific Claims Tribunal of Canada ${ }^{2}$ condemned the federal government of Canada for failing "to honour its legal, statutory and fiduciary duties" to the Atikamekw of Opitciwan (previously known as the Atikamekw of Kikendatch) when the provincial government of Quebec constructed the dam and impounded the reservoir between 1915 and 1918 (SCT).

For centuries, the Atikamekw had frequented the headwaters of the Saint-Maurice River in small nomadic hunting bands. Despite this millennial occupancy of the Saint-Maurice water-

1. We gratefully acknowledge the resourcefulness of Sylvie Létourneau at the Service documentaire du Conseil de la Nation Atikamekw (La Tuque) and Caroline Rouleau at the Hydro-Quebec Archives (Montreal) for their help in documenting this research. We also thank the guest editors, Manlio Della Marca and Uwe Lübken, as well as the anonymous reviewers, for their useful comments.

2. An independent adjudicative body appointed by the Canadian federal government in 2008, the Specific Claims Tribunal (SCT) aims to resolve, mainly but not exclusively, monetary disputes between a First Nation and the Crown (SCT 2020).
Stéphane Castonguay Université du Ouébec à Trois-Rivières

Canada

and

Hubert Samson

Groupe DDM,

Ouebec City

Canada

(iD) (D) 
shed, the bones torn free by the waters of the reservoir were rare evidence of their ancestral presence in the area. The rapid industrialization of the river and its watershed during the first decades of the twentieth century had materially and symbolically transformed the living environment of the Atikamekw and concealed their markers of occupancy.

This article investigates the reconfiguration of the Atikamekw territoriality within the watershed of the Saint-Maurice River between 1850 and 1930. During that period, Euro-Canadians accentuated their presence in the traditional territory of the Atikamekw by building industrial infrastructure and exploiting natural resources, in particular hydropower and pulpwood. For the cultural geographer Claude Raffestin, territoriality is a set of complex relationships mediated by techniques and representation, and that unites a human group and its material and spatio-temporal environment (Raffestin 1986: 93). ${ }^{3}$ Deterritorialization refers to the reorganization of these systems of relationships, as one replaces another (91). As the industrial reconfiguration of the river and its watershed impacted the social practices of the Atikamekw, it potentially constituted an act of deterritorialization. After reviewing the ethnohistorical and anthropological elements of the Atikamekw spatial practices, the article turns to the Atikamekw and Euro-Canadian territorialities and explores the differences in their geographic imaginations.

Rivers of the Americas

THE SOCIAL PRACTICES AND TERRITORIALITIES OF THE ATIKAMEKW

In the middle of the nineteenth century, more than two hundred Atikamekw inhabited the Upper-Mauricie (Gélinas 2003). Today more than seven thousand individuals are distributed in three communities-Opitciwan, Wemotaci and Manawan-which closely correspond to the territory of their traditional semi-nomadic bands (Poirier 2001: 143). Despite the fact that they share a com-

3. In his understanding of territoriality, political geographer Robert Sack insists on the strategic dimensions of spatial productions to exercise control over a given area (Sack 1986). On the complementarity between Raffestin and Sack, see Murphy (2012). Éthier and Poirier articulate a specific understanding of indigenous territorialities as it relates to the Atikamekw Nehirowisiwok of Upper-Mauricie (2018: 107). 
mon language and culture, rarely have these three communities expressed the need for a unique political representation. In fact, the ethnonym Atikamekw Sipi gained currency late in the twentieth century, and even within the Atikamekw Nation Council, each community remained largely autonomous (Célinas 2003: 187-188).

Nitaskinan, the traditional territory of the Atikamekw, covers the watershed of the Saint-Maurice River, where today they still find the resources that have long been central to their subsistence and commercial activities (Nehirowisiw Kitci Atisokan). At the headwaters of the Saint-Maurice River, the Atikamekw break into smaller groups to hunt large game animals and trap fur-bearing animals, a model of social organization that brings together members of the same family on delimited hunting grounds (Célinas 2003: 152). Along with other natural markers such as lakes and mountains, the many tributaries of the SaintMaurice river, which gave the river its name Tapiskwan Sipi (the river where several streams flow), are used to distribute the territory among the hunting groups (Coocoo 2015). Hunters also leave marks on the territory (notches on trees, for example) to delimit their area of activity and signal their presence. These markers of occupancy signify to other members of the community that the area is occupied, sometimes also indicating the number of beavers that the hunting group plans to collect (Poirier 2004: 140). Markers like these form part of the spatial distribution of the Atikamekw and the collective organization of their activities in the territory. Although they are flexible and do not prevent hunters from pursuing mobile prey across boundaries, on some level these markers regulate access to the territory. They convey a language understood and shared by all members of the community. This mode of spatial organization allows the Atikamekw to occupy the territory and exploit its resources, and to respect certain rules of life in society.

The spatial distribution of the Atikamekw also depends on seasonal cycles and the availability of resources across a given territory. The Atikamekw recognize the existence of six seasons (autumn, pre-winter, winter, pre-spring, spring, and summer), each corresponding to a particular state of the territory and a specific activity, whether it be fishing, big game hunting, trapping, or gathering 
(Poirier 2004: 140). The cycle of the six seasons also modulates travel and subsistence activities in the territory.

According to anthropologist Paul Charest, Indigenous communities living by hunting and fishing develop functional adaptation strategies for environmental resources: subsistence activities combine and follow one another according to the changing constraints of a territory at different times of the year (1975: 37). These strategies nevertheless require a perceptive knowledge of the territory, which is why the Atikamekw learn from a very young age to read the signs and the traces that animals leave (bites, tracks, trails, excrement, etc.), thanks to elders who act as guides, passing on their knowledge and skills to the younger generations. Knowledge is transmitted through hunting stories told by the elders in the form of myths and legends (Éthier 2018). Anthropologist Sylvie Poirier explains that, in a society with an oral tradition like that of the Atikamekw, stories are part of a process of socialization through which members of the community learn the values and codes of their group. It is also a means by which the elders share their experiences, practices and know-how from living in the forest (Poirier 2001: 138-139). Younger generations learn the basics of hunting, trapping, and fishing, which form all the knowledge necessary to their subsistence (141).

Oral tradition turns the territory into a place of discourses that nurture both the cultural identity and the territorial knowledge of the Atikamekw (Éthier et Poirier 2018: 111). Place naming

Rivers of the Americas enables the Atikamekw to symbolically appropriate the territory and impart on it a part of themselves-their activities, their emotions, their memories. From this perspective, the territory acts as both a witness to and a guardian of the cultural identity of its occupants by reflecting an image of themselves. The Atikamekw therefore do not see the territory as a mere physical space; rather, they develop a state of emotional and subjective consciousness of it (Poirier 2001). The territory is found within narratives, stories, and beliefs that emerge from the mosaic of physical and metaphysical relationships that the Atikamekw have with each other and with their living environment.

For the Atikamekw, this mode of representation has determined their way of being, of thinking, and of living since their establishment 
in the Upper-Mauricie, centuries before the arrival of Euro-Canadians. While the territory still constitutes the foundation of their cosmology, their culture, and their identity, the industrial transformation of the Upper Saint-Maurice River has profoundly reshaped the Atikamekw territoriality.

INITIAL TERRITORIAL TRANSFORMATIONS

OF THE UPPER SAINT-MAURICE RIVER

From the second half of the nineteenth century, the intrusion of Euro-Canadians in Upper-Mauricie-the area surrounding the Upper Saint-Maurice River-led to changes in the territorial practices of the Atikamekw. Loggers gradually encroached on the hunting territory of the Atikamekw starting in 1847, when they obtained cutting rights and established logging camps in the region. Logging began one year after the colonial government of the Province of Canada repelled the monopoly previously held by the Forges du Saint-Maurice, an ironworking industry, on the banks of the Lower Saint-Maurice (Hardy and Séguin 2004: 160). The monopoly had prevented the colonization of the valley by Euro-Canadian settlers, but after its removal, the Saint-Maurice River acted as a route for exploration of the upper reach of the river. The colonial government then proceeded to survey the land and lease timber limits, and opened the valley to more intensive logging. In 1852, it undertook the construction of a series of dams and log slides on the Saint-Maurice River and its tributaries to facilitate forest exploitation, particularly in difficult-to-access areas. These public works transformed the riverine environment, turning the watercourses into corridors for transporting wood by timber floating and accessing the northern and inland territories (405).

With the expansion of forestry activities across the watershed, the availability of wildlife decreased, as did the hunting area of the Atikamekw. During the 1860s, the cutting sectors encroached on the southern portion of the traditional territory of the Atikamekw. Loggers operated along the main tributaries of the Saint-Maurice, such as the Mattawin, Manawam, Vermillon, Wessonneau, and Rat rivers. Logging drew thousands of lumbermen, and the Euro-Canadian presence became increasingly pervasive across the watershed of the Upper Saint-Maurice. The massive 
migration of lumbermen had an impact on the resources of the territory, as many engaged in poaching activities and inadvertently caused forest fires around logging sites and hunting grounds (Hardy and Séguin 2004: 183). The transformation of the forest environment by logging activities in the Upper-Mauricie caused the moose population to decline starting in the middle of the century (Célinas 2003: 353). With the depletion of game and the degradation of wildlife habitats, it became increasingly difficult for the Atikamekw to practice their hunting and trapping activities.

Given the scarcity of the moose and other big game species they needed to feed themselves and make their clothes, the Atikamekw became dependent on fur-bearing animals. They had been involved in the fur trade since the seventeenth century, but only in the second half of the nineteenth century did the Atikamekw specialize in this type of activity (Célinas 2003: 15). Beginning in 1827, the Hudson's Bay Company operated trading posts close to "Indian reserves," at Opitciwan and Kikendatch, where the Atikamekw exchanged furs for essential goods (food, tools, clothing). As the nineteenth century wore on, Euro-Canadian intrusion continued to challenge the traditional subsistence activities of the Atikamekw by causing further environmental degradation and further limiting the availability of wildlife, drawing them closer to a market economy (117). Hunting grounds became less and less viable, and, in some cases, were no longer sufficient to meet the food needs of the Atikamekw hunters, especially when small game became the target of Euro-

Rivers of the Americas Canadian poachers.

The fragmentation of the forest and the disappearance of game increased the sense of urgency among the Atikamekw. Logging, poaching, and forest fires prompted them to petition the federal Department of Indian Affairs in 1895 for reserves and protection of portions of their hunting grounds. Provided for under the Indian Act of 1876, reserves were meant to establish exclusive access to a territory. The Atikamekw's petition aimed to protect their subsistence activities from the impact of Euro-Canadian activities and to preserve their mode of production based on hunting and trapping (Célinas 2002: 39). The challenge was to find a suitable location that met both the requirements of the Atikamekw and the obligations of the Quebec government towards the holders 
of timber licenses, as large forest areas in the Upper-Mauricie had already been leased to Euro-Canadian loggers. The Department of Indian Affairs finally granted the reserves of Wemotaci (1895), Coucoucache (1895), and Manawan (1906) (MAl 1906: 34). In 1908, a fourth application for a reserve initially targeted a land tract around the Hudson's Bay Company fur trading post in Kikendatch, but efforts to create a reserve were redirected in 1912 after the Hudson's Bay Company moved its post downstream on the Saint-Maurice River, to the outlet of Lake Opitciwan.

Despite the creation of these reserves, the Atikamekw did not obtain adequate access to their hunting grounds. The reserves did not prove large enough to cope with the growing encroachment of Euro-Canadians, and were deemed too small to ensure the subsistence of the Atikamekw. Shortly after their creation, the reserves of Wemotaci and Coucoucache became obstacles to logging activities and their existence in the territory was discredited by government agencies and timber companies (Bouchard 1980: 150-153). In the 1890s, the Department of Indian Affairs obtained the legal right to expropriate parts of reserves by using a legal provision of the Indian Act meant to facilitate the development of public works in the territory. In 1911, an amendment to the Indian Act specified that the requirements of private companies and local governments could legitimate the expropriation of reserves (Célinas 2002: 39). This legislative amendment was in line with the industrial demands of the early twentieth century.

While in the first half of the nineteenth century the presence of Euro-Canadians in the Upper Saint-Maurice Valley was limited to fur traders and members of the Congregation of the Missionary Oblates of Mary Immaculate, Euro-Canadian territorial ambitions increased with the opening of the Saint-Maurice River and the expansion of logging activities after 1852. It was also at that stage that Euro-Canadians began to industrialize the Saint-Maurice River and intensify the exploitation of its natural resources.

\section{EURO-CANADIAN TERRITORIALITY AND THE STRUCTURATION OF THE SAINT-MAURICE WATERSHED}

The establishment of an industrial infrastructure on the SaintMaurice River at the start of the twentieth century was part 
of a process of territorial appropriation by Euro-Canadians whereby they established their territoriality across the watershed with the appearance of new markers of occupancy. Industrialists transformed the river for the transportation of wood, the production of energy, and the manufacture of pulp and paper. Subsequently, the "will to improve" (Li 2007) the Upper Saint-Maurice prompted Euro-Canadians to undertake a new series of interventions that embrittled the territorial foundations of the Atikamekw.

Euro-Canadians extended and consolidated their territorial ambitions by dotting the northern reach of the Saint-Maurice River with industrial and urban infrastructure. $\ln 1889$, the Laurentide Pulp Company completed the construction of a pulp and paper mill and a hydroelectric dam on the west bank of the Saint-Maurice, in the parish of Ste-Flore; ${ }^{4}$ the Laurentide also exploited 800 square kilometers of forest reserves in the region (Niosi 1975: 380). That same year, the Belgo Pulp and Paper Company built a mill at the foot of the Shawinigan Falls (Lanthier and Gamelin 1981: 186), where the Shawinigan Water and Power Company completed the construction of a hydraulic dam the following year (Bellavance 1994: 46); the Belgo held timber limits along the Grand Bostonnais River (Sieyer 1907). Between 1907 and 1910, the Brown Corporation (then known as the Quebec and St. Maurice Industrial Company) built a chemical pulp mill and a hydraulic dam on the eastern portion of the Saint-Maurice at La Tuque. Its manufacturing activities necessitated pulpwood that the company obtained from timber

Rivers of the Americas berths in Upper-Mauricie (Lanthier and Gamelin 1981: 216-217). Thus, the construction of an industrial infrastructure, the creation of new production centers, and the emergence of small villages and company towns led to the reorganization of the Saint-Maurice River and its watershed.

With the start of the second industrial revolution-a period marked by the intense exploitation of natural resources in the region following technoscientific developments in the field of electricity and chemistry (Caron 1997)-Euro-Canadians changed their perception of the territory and multiplied their markers of occupancy. Resources that were previously eschewed or neglected were

4. The working-class district adjacent to the factory took the name "Grand-Mère" in 1898 and obtained a municipal charter in 1901. 
assigned an economic value theretofore unseen. Tree species that prevented the growth of the valuable pine, such as black spruce and balsam fir, became the main staples of the pulp and paper industry. As more wood could be cut, the value of the timber limits increased, and so did the royalties collected by the state. New portions of the territory were becoming productive, and to meet the growing demand of the pulp and paper industry, the state delimited new timber limits north of the Upper Saint-Maurice River, on the "wasted lands" that the Crown had not yet leased. The beginning of the twentieth century therefore marked the intensification of logging and widening of logging sectors within the watershed of the Saint-Maurice River.

Likewise, the emergence of hydroelectricity changed the EuroCanadian representation of the Saint-Maurice River. Falls and rapids were initially perceived as an impediment to lumber operations in the nineteenth century, forcing the colonial government to invest heavily in the construction of dams and slides for log driving. Eventually, they became assets for the production of the hydropower to supply not only urban centers, but also the energy-intensive industries of the second industrial revolution, such as chemical pulp manufacturing. Attracted by the abundant reserves of natural resource within the watershed, Euro-Canadians transformed the Upper Saint-Maurice River to allow for the production of hydroelectric energy as well as the collection and transportation of forest resources. ${ }^{5}$

As industrial activities in the region intensified at the beginning of the twentieth century, improvement of the Saint-Maurice River and regulation of its flow became a necessity for the Euro-Canadians. It also led to a reordering of the territory. Pulp and paper companies recommissioned old dams and built new ones in areas recently leased by the state. Work teams dynamited river beds, cut riparian vegetation, and removed tree trunks to prevent logs from piling up. Forest operators built small dams at the outlets of lakes to store the water needed to facilitate log driving. As the opening

5. The strongest hydraulic flows are at the falls at La Gabelle, Shawinigan Falls, Grand-Mère, La Tuque, and La Trenche and the rapids at Rapide Sans-Nom, Rapide Blanc, Rapide des Cœurs, Rapide Lièvre, and Rapide Allard (see fig. 1). 
of the dam gates raised the water level downstream, it was also necessary to construct docks to protect the banks from erosion, and palisades to guide the driftwood and avoid "strays" from landing on the banks. Euro-Canadians thus reconfigured the hydrographic basin of the Saint-Maurice River to facilitate lumber operations.

The hydrological variations of the Saint-Maurice River encouraged Euro-Canadians to carry out large-scale improvement schemes on the river. In fact, seasonal low-water periods reduced the production capacity of hydroelectric power plants, in addition to hampering log-driving operations that supplied the pulp and paper mills (CECQ 1912: 14). Motivated by a common desire to regulate the flow of the Saint-Maurice River, the Shawinigan Water and Power Company and the region's forest operators created the St. Maurice Hydraulic Company in 1909 to build water storage dams upstream. ${ }^{6}$ The first initiative of the St. Maurice Hydraulic Company was to rebuild the old dams used by forest operators for log driving, as increasing their water retention capacity

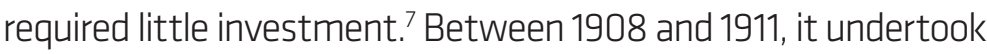
the reconstruction of dams on the Manouane River ("Reservoir $A B C$ " on fig. 1, on the facing page), built some forty years earlier, to give a complementary purpose to the storage of water: that of regulating the flow of the Saint-Maurice River for the transportation of pulpwood and the production of hydroelectric energy. ${ }^{8}$

The improvement of the Manouane River constituted a first

Rivers of the Americas step in the regulation of the Saint-Maurice River and paved the way for larger-scale projects in Upper-Mauricie. In 1912, after having completed the three dams on the Manouane River, the St. Maurice

6. The regulation company was made up of the Canada Iron Corporation Ltd. (Trois-Rivières), the Quebec and St. Maurice Industrial Co. Ltd. (which later became the Brown Corporation, in La Tuque), the Laurentide Company Ltd. (Grand-Mère), Shawinigan Water and Power Company (Shawinigan Falls), the Union Bag and Paper Co. (Cap-de-la-Madeleine), the Grès Falls Co. (a subsidiary of Union Bag and Paper Co. that owned the water power rights for La Cabelle), the St. Maurice Driving and Improvement Association and the St. Maurice River Boom and Driving Co. Ltd. (McDougall 1912). 7. From a letter by E.E. Taché, the Minister of Lands and Forests of Quebec to Thomas McDougall, Vice President of Shawinigan Water and Power Company (29 Nov. 1909).

8. From a letter by Thomas McDougall to E.E. Taché (5 Feb. 1912). 


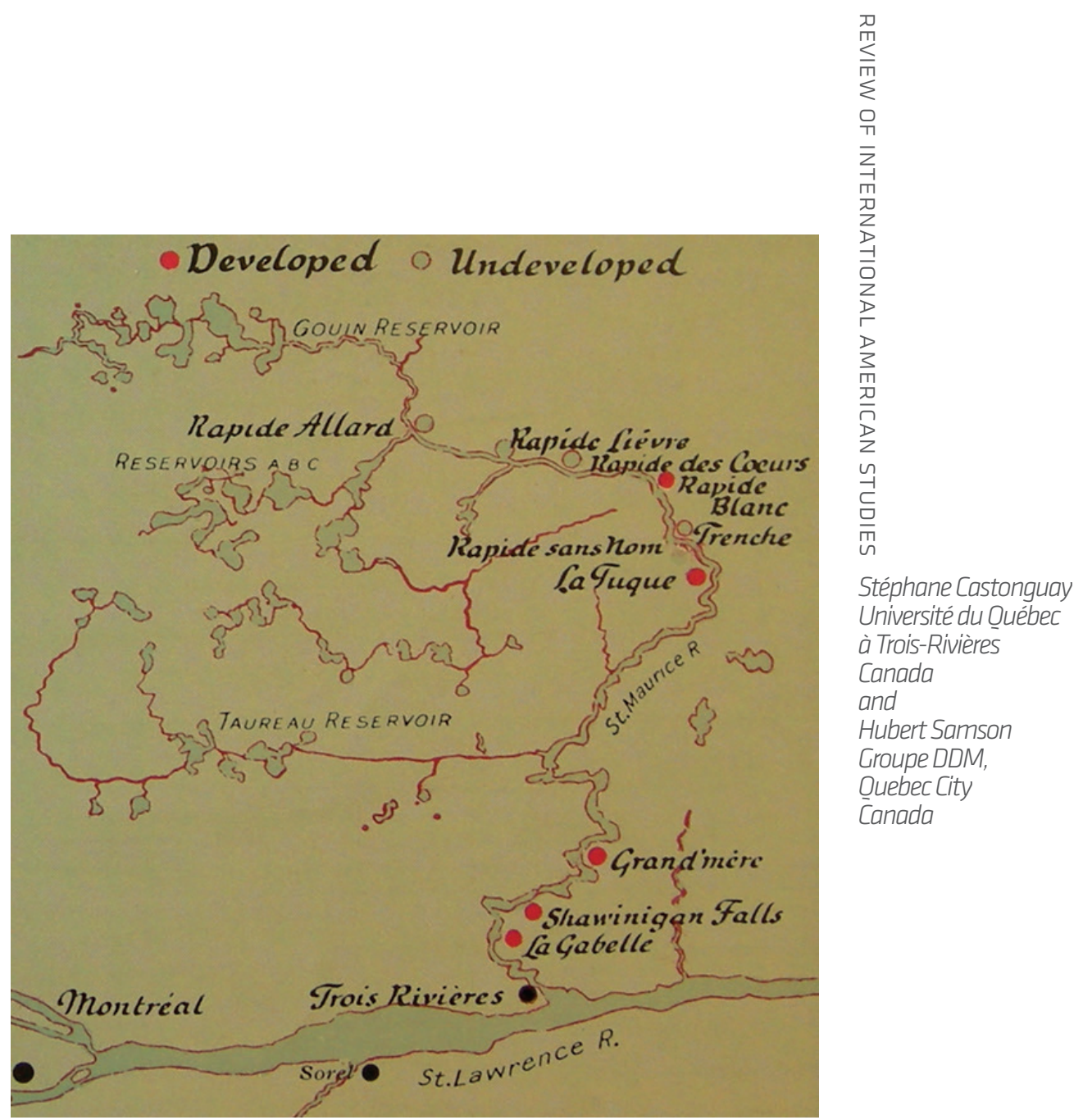

Fig. 1. Map of Power Plants on the Saint-Maurice River (Shawinigan Water and Power Company 1942: diagram A).. 
Hydraulic Company requested authorization to merge the headwater lakes of the Saint-Maurice River and create a large reservoir. Because it feared conflict among the industrial users of the river, the provincial government handed the project over to the Quebec Streams Commission, a public agency responsible for surveying hydraulic resources, carrying out field studies, and building storage dams to regulate the flow of water (Lefebvre 1920: 343). The state was then involved in planning the construction of a reservoir dam a few kilometers upstream from the La Loutre Rapids, on the Upper Saint-Maurice River (Samson 2014).

Because it needed to link the construction site to the rest of the region, the Quebec Streams Commission launched the industrial colonization of the watershed by building the infrastructure needed to transport men and goods to the La Loutre Rapids. A series of relay stations and transit points appeared across the territory. One of them, the village of Sanmaur, built on the banks of the Saint-Maurice River across from Wemotaci, acted as a hub for travel to the mid-north, with workers, food supplies, machinery, and construction materials arriving there by train. Part of the work consisted of dredging the bed of the Saint-Maurice River to clear the navigation channel between the Sanmaur substation and the Chaudière Rapid upstream. A railway segment was built between the Chaudière Rapid and the proposed site for the reservoir dam to avoid a series of rapids that breaks the course of the river. ${ }^{9}$

Rivers of the Americas As the materials needed to develop the reservoir were sourced across the region, development of interconnections within the territory continued after dam construction started. ${ }^{10}$ The activities upstream from the La Loutre Rapids reproduced on a smaller scale the larger, integrated system that Euro-Canadians established throughout the region during the first decades of the twentieth century to exploit the natural resources.

9. These were Windigo Falls (9 feet), Petit Rocher (9 feet), Mountain (35 feet), Birch ( 9 feet), Cypress (25 feet) and La Loutre (17 feet) (CECQ191614). 10. Structural timber used for buildings, formwork and cofferdams in particular. Hydro-Québec Archives, Shawinigan Water and Power Company collection, F01/3716, Contract between the Brown Corporation and the St. Maurice Construction Company, 10 November 1915. 
The completion of the La Loutre Reservoir (renamed the Gouin Reservoir in 1919) at the end of 1917 marked a turning point in the consolidation of industrial activities across the territory of the Saint-Maurice Valley (Samson 2014).11 The increase in water power-the constant flow reached 12,000 cubic feet per second, double the natural flow-led Euro-Canadians to consider building other hydroelectric facilities. The Shawinigan Water and Power Company entered into an agreement with other holders of hydraulic power licenses to create a hydroelectric production network along the Lower Saint-Maurice River. First, with the Laurentide Paper Company, it improved the Grand-Mère dam in 1915, just when the Quebec Streams Commission was starting its survey activities at the La Loutre Rapids (Kaelin 1919). Later, in 1923, it constructed a hydroelectric dam at La Gabelle with the Grès Falls Company, another paper manufacturer ("Une filiale à la Shawinigan"). Thanks to the additional flow provided by the reservoir, the Shawinigan Water and Power Company was eventually able to extract more hydropower from the Saint-Maurice River and use these dams to their full potential (see fig. 1).

Completion of the water regulation system also improved lumber operations across the watershed of the Saint-Maurice River and facilitated intensive logging activity over a larger portion of the territory. As the logging sites moved northward, the Gouin Reservoir played a crucial role in forestry operations from the $1920 \mathrm{~s}$ on. The regulation of the river flow by the reservoir spared forestry operators the loss of wood along the banks during log driving operations (CECQ 1921: 10). On certain occasions, the Quebec Streams Commission also released a large amount of water to dislodge ice jams, as was the case in 1919, when more than a million logs remained blocked at Blanc Rapid (CECQ 1919: 19). The installation of the Manouane reservoirs had already made it possible to control the flow of water over a large part of the Saint-Maurice River, but the completion of the Gouin Reservoir brought the entire course of the river under control.

In addition to facilitating the transit of wood to pulp and paper mills, the reservoir dams on the Upper Saint-Maurice consoli-

11. First known as "La Loutre," the dam was officially named the Gouin dam in 1919, in honor of Lomer Gouin, Premier of Quebec between 1905 and 1920. 
dated the exploitation of the forest in the north, especially along the Manouane River and the La Loutre Rapids, where the Laurentide Company and the Brown Corporation concentrated their logging activities beginning in the early 1920s (Samson 2014). The bodies of water created by the dams enabled these companies to access new sections of the wooded portions of the watershed for pulpwood. As these companies incorporated the water regulation works into their own production networks, the reservoirs facilitated the inland incursion of pulp and paper companies and became an integral part of the Euro-Canadian territoriality in the Upper Saint-Maurice.

ENVIRONMENTAL DISRUPTIONS

AND THE CONFRONTATION OF GEOGRAPHICAL IMAGINATIONS

The quest for raw material and energy led Euro-Canadians to resettle the territory of the Upper-Mauricie and transform the river and its watershed to meet industrial needs. The industrialization of the river entailed the territorial dispossession of the first occupants and the mutation of their territoriality following the environmental disruptions provoked by the intensification of logging activities and the multiplication of water regulation works. Indeed, from the Atikamekw perspective, Euro-Canadians superimposed new markers of occupancy on their territory, thereby reducing the visibility of their presence and generating a phenomenon of deterritorialization.

Rivers of the Americas

The first step in the process of territorial appropriation by EuroCanadians rested in the production and accumulation of territorial knowledge in order to facilitate the exploitation of natural resources in Upper-Mauricie. The Quebec government and large corporations mandated surveyors and engineers to produce surveys and maps of the region. By collecting a specific type of data in the fieldthose relating to potential natural resources and their possible exploitation-they produced a simplified vision of the territory, a form of "map-planning" (Bocking 1972: 68), whereby the watershed of the Upper Saint-Maurice appeared as a set of values and blueprints for the extraction of pulpwood and the generation of hydroelectricity. These spatial representations left very little room for the Atikamekw to signal their presence and the specific- 
ity of their spatial practices. While surveyors noted that the soil around the La Loutre Rapids lacked any agricultural potential, they were silent on the existence of the fish and game resources that were central to the Atikamekw (CECQ 1912: 111). Even before Euro-Canadians undertook the construction of the Gouin Reservoir, the Atikamekw had been essentially wiped from the territory by not featuring in the geographic imagination of Euro-Canadians. When asked by the president of the Quebec Streams Commission, Simon-Napoléon Parent, whether anyone would suffer damages due to the improvement of the river, the St. Maurice Hydraulic Company president answered: "I do not know of anyone" (CECQ 1912: 109). Atikamekw living in Kikendatch were only notified at the last minute. One informant later recalled: "The first thing we learned from the project manager for the construction of the dam was that the location of our meeting place was going to be flooded. And no one knew much more to be able to protest." (qtd. in Léger 1983: 176).

The exploitation of the territory by Euro-Canadians subsequently transformed the familiar landscape of the Atikamekw and the way they experienced their living environment. The construction of reservoir dams on the Upper Saint-Maurice and the spread of logging activities changed the territory. During the impoundment of the Gouin Reservoir, for example, raising the water level caused the flooding of some 100 square miles of land in the heart of the Atikamekw hunting territory. It also drowned the gathering site of Kikendatch under fifteen meters of water and partially inundated the village at the outlet of Lake Opitciwan. The cemetery and some sixty graves were also inundated, as were the hunting camps outside the village. The floodwaters reached the trading post of the Hudson's Bay Company, which not only had been notified in advance but had also received monetary compensation for its moving costs. The village of Kikendatch was also flooded in 1919 and 1920 but, according to elders who testified at the Special Claims Tribunal, "They were only able to save their blankets and clothing" (SCT 2016: 60), while their houses drifted and their personal belongings drowned.

Euro-Canadians' industrial activities also caused the disappearance of the landmarks underlying the spatial practices and the socio- 
territorial organization of the Atikamekw (Fortin 1979: 31), sometimes affecting their capacity to orient themselves in this remodeled territory. For example, rather than navigating through a string of lakes at the headwaters of the Saint-Maurice, canoers faced the Couin Reservoir, a large, undifferentiated body of water with high winds, turbulent waves, and unstable water levels (Jéröme Méquish, qtd. in Chachai and Chachai 2011). Environmental transformations also destabilized the hunting grounds, as well as their distribution and transmission, which were based on the physical attributes of the territory. Furthermore, because the engineers decided to flood the territory without removing the trees, the emaciated silhouettes of the submerged trees were decades-long reminders of the shock caused by the construction of the Gouin Reservoir. ${ }^{12}$ These changes forced the Atikamekw to internalize new spatial signs that acknowledged the degradation of the environment and their increasingly dwindling living environment.

Environmental transformations also prevented the Atikamekw from moving freely across the territory. Canoeing became dangerous after the impoundment of the reservoir. The flooded vegetation created impassable barriers along the banks. The reservoir water level rose and fell according to the needs of the Quebec Streams Commission. In winter, these fluctuations weakened the ice and created hazards for those who ventured along frozen waterways. Steel-hulled boats facilitated navigation through the debris-laden waters of the Gouin Reservoir, but the submerged trees pierced

Rivers of the Americas the Atikamekw bark canoes and the wind and waves rendered canoeing more difficult (Bouchard 1980: 161). Under these conditions, the Atikamekw found it difficult to reach their gathering places and hunting and trapping sites located at the water's edge (Nehirowisiw Kitci Atisokan 2014:87).

In addition to limiting access to the territory, Euro-Canadians industrial activities had an impact on the subsistence capacity of the Atikamekw. Logging and forest fires had already reduced game habitats and hunting and trapping areas during the second half of the nineteenth century. At the beginning of the twentieth

12. According to the engineers, it was not economically profitable to log this sector as the territory to be flooded was only a vast expanse of marshes, forests ravaged by fire and land unfit for cultivation ("The Gouin Dam"). 
century, the proliferation of construction sites and transportation routes accentuated the risk of fires, especially after logging companies intensified their cutting activities in the region. At the same time, the reservoir dams built on the Saint-Maurice and its tributaries flooded the hunting grounds of the Atikamekw and disrupted the local ecosystem. By altering the reproductive cycles, spawning sites, and eating habits of fish communities, the dams reduced the amount of fish, a staple of the Atikamekw diet (E.D.S. Inter inc. 1989: 85). During the hearings of the Special Claims Tribunal, the elders testified that the flooding of the land, the decomposition of wood, and the drowning of animals also caused water contamination and episodes of illness and death among the human population (SCT 2016: 60). Recounting the oral histories transmitted to them by their elders, Jérémie and David Chachai of the Atikamekw d'Opitciwan First Nation "mentioned the carcasses of moose that had drowned because they had become disoriented and that were now floating in the reservoir, drowned beavers trapped in cages, birds and birds' nests that had been submerged by the waters" (125). Furthermore, given that wildlife proliferated on lakeshores and riverbanks, the reconfiguration of watercourses degraded the habitat and feeding sites of fur-bearing animals, big game, and waterfowl and caused their reproduction rates to fall in the years following the impoundment of the Gouin Reservoir (Fortin 1979: 22). The rise in the water level therefore led to the decline and migration of fauna, conditions under which many Atikamekw families were no longer able to make a living from their shoreline hunting grounds.

Not knowing where to go, hunters had to relocate to the outskirts of flooded areas and modify their portage routes and itineraries (Éthier and Poirier 2018: 108). Their convergence in areas spared by industry nevertheless increased theecological load and hunting pressures. Due to the disappearance of hunting grounds and the depletion of wildlife, it became more difficult for Atikamekw hunters to maintain their conservation practices, such as leaving at least one pair of beavers per lodge or alternating between trapping grounds (Bouchard 1980: 194-195). At the end of the 1930s, the missionary Joseph-Étienne Guinard pointed out that famine occurred more frequently among the Atikamekw, who had to rely more and more often on the Department of Indian Affairs to ensure their survival ("Le Père Guinard" 
1939: 10). The Atikamekw thus developed a state of dependence on the department, coincidentally allowing Euro-Canadians to increase their administrative control over the Upper-Mauricie.

Eventually, the forced withdrawal of the Atikamekw from areas exploited by Euro-Canadians, the disappearance of their identity referents, the loss of their territorial bases, and the difficulty of maintaining their traditional subsistence practices interfered with the Atikamekw process of cultural transmission. The loss of access to the territory created an intergenerational break, as it was in the forest that the elders passed on their knowledge to the younger people and that the myths materialized. ${ }^{13}$ Among the Atikamekw, the preservation of customs and the construction of culture required a collective imagination based on knowledge of, and acquaintance with, the territory (Poirier 2001: 112), but environmental transformations limited their ability to preserve their way of life and their ancestral practices.

Industrialization therefore acted as a de-territorializing force by obliterating the markers of occupancy initially found in the territory (Sack 1986). It dislocated the history and identity of the Atikamekw, as their presence and sites of memory became less visible. Areas degraded by industry lay at the heart of the Atikamekw's way of life and community organization; these had been hunting grounds, meeting points, and geographical landmarks (Poirier 2001: 105). Even after they were permanently flooded, these significant places con-

Rivers of the Americas tinued to be identified by the Atikamekw as part of their traditional territory (McNulty and Cilbert 1981: 212), although several of these areas ceased to be living environments for the Atikamekw (Célinas 2002: 45). Yet, despite its negative social and environmental impacts, industrialization offered the Atikamekw economic opportunities and an alternative to the fur trade, which had started to become a less stable source of income. Like other Indigenous communities in the middle-north of Quebec, the Atikamekw turned to wage labor, with some working as guides for explorers, tourists, and sport

13. Other factors in the second half of the twentieth century included the forced attendance of residential schools, the growing sedentarization of the Atikamekw people and an elevation of the crest of the dam in 1948 (Poirier 2000: 144). 
hunters, and others becoming forest workers on the logging sites of the Upper-Mauricie (Labrecque 1984: 82).

\section{CONCLUSION}

From the first decades of the twentieth century, Euro-Canadians imprinted symbolic and material markers that concealed what initially existed in the territory of the Upper-Mauricie and that were the very foundations of their territoriality. The flooding of the land resulting from the impoundment of the reservoir erased points that anchored the Atikamekw to the territory, whether geographical or identity markers, sites of memories, gathering places, cemeteries, or hunting and trapping grounds. Euro-Canadians superimposed a spatial grid on the Atikamekw system of exchange, communication and production.

Deterritorialization tools such as surveys and maps and the infrastructural reconfiguration of the Saint-Maurice River transformed the Upper-Mauricie into an industrial system intended for the production of hydroelectric energy and the transportation of pulpwood. In this process of deterritorialization, the industrialization of the Saint-Maurice River and its watershed disturbed the Atikamekw's way of life, their social organization and their geographical imagination. In the past, the Atikamekw had adapted to natural fluctuations in the biotope, but what can be said about the anthropogenic changes to the watershed of the Upper Saint-Maurice River that followed the intrusion of Euro-Canadians? When the Atikamekw faced another series of upheavals in the 1940s and 1950s (the spread of logging sectors on the periphery of the Gouin Reservoir, the construction of other hydroelectric dams in Upper-Mauricie, the closure of the Hudson's Bay Company trading posts, the raising of the crest of the Couin dam, and the enlargement of the reservoir), these changes were simply an extension of what they had been experiencing for the pastcentury. Moreover, their nomadic reality had always demanded adaptation strategies. Their testimonies during the hearings of the Specific Claims Tribunal of Canada were another illustration that, despite the material transformations of the watershed, the Atikamekw maintained their traditional relationship with the territory rather than having had their identity succumb to a historical break. 
WORKS CITED:

Bellavance, Claude. Shawinigan Water and Power, 1898-1963, formation et déclin d'un groupe industriel au Québec. Boréal, 1994.

Bocking, Richard C. Canada's Water: For Sale? John Lewis \& Samuel, 1972

Bouchard, Serge. Mémoires d'un simple missionnaire : le père JosephÉtienne Guinard, o.m.i., 1864-1965. Ministère des Affaires culturelles, 1980.

Caron, François. Les deux révolutions industrielles au XXe siècle. Albin Michel, 1997.

Chachai, Denis, and Siméon Chachai, directors. Kikendach. Wapikoni Mobile, 2011. Wapikoni, www.wapikoni.ca/films/kikendatch.

Charest, Paul. "Les ressources naturelles de la Côte-Nord ou la richesse des autres une analyse diachronique." Recherches amérindiennes au Québec, vol. 5, no. 2, 1975, pp. 35-52.

CECQ [Commission des eaux courantes du Québec / Quebec Streams Commission]. Rapport annuel, 1912.

------. Rapport annuel. CECQ, 1916.

------. Rapport annuel. CECQ, 1919.

------. Rapport annuel. CECQ, 1921.

Coocoo, Bryan, director. Tapiskwam Sipi (La rivière Tapiskwan). Wapikoni Mobile, 2015. Wapikoni, www.wapikoni.ca/films/tapiskwansipi-la-riviere-tapiskwan.

Rivers of the Americas

Devreese, D. "La coupe du bois." Le Nouveau Trois-Rivières, 7 June 1912, p. 6.

E.D.S. Inter inc. Aménagement hydro-électrique du Haut-Saint-Maurice: Utilisation du territoire par les Atikamekw et inondation partielle de la réserve de Wemotaci. Hydro-Québec, 1989.

Éthier, Benoit. "Nehirowisiw Kiskeritamowina : acquisition, utilisation et transmission de savoir-faire et de savoir-être dans un monde de chasseurs." Recherches amérindiennes au Québec, vol. 44, no. 1, 2014, pp. 49-59. https://doi.org/10.7202/1027879ar

Éthier, Benoit, and Sylvie Poirier. "Territorialité et territoires de chasse familiaux chez les Atikamekw Nehirowisiwok dans le contexte contemporain." Anthropologica, vol. 60, no. 1, 2018, pp. 106118. https://doi.org/10.3138/anth.60.1.t11 
"Une filiale à la Shawinigan." Le Nouvelliste (Trois-Rivières), 13 Jan. 1923, p. 5.

Fortin, Gérard. Éléments d'étude des impacts des barrages-réservoirs de la Haute-Mauricie sur le territoire ancestral des Attikameks. Conseil Attikamek-Montagnais, 1979.

Gélinas, Claude. "La création des réserves Atikamekw en Haute-Mauricie (1895-1950), ou quand l'indien était vraiment un indien." Recherches amérindiennes au Québec, vol. 12, no. 2, 2002, pp. 39-48.

------. Entre l'assommoir et le godendart. Les Atikamekw et la conquête du Moyen-Nord québécois, 1870-1940. Septentrion, 2003.

"The Gouin Dam." The Engineering Journal, Sept. 1923, p. 558.

Hardy, René, and Normand Séguin. Histoire de la Mauricie. Presses de l'Université Laval, 2004.

Kaelin, F.T. "Power developments on the St. Maurice river. The history of the development of the water falls of the St. Maurice river centered at Shawinigan Falls, showing their relation to possible future industrial progress." The Canadian Chemical Journal, vol. 3, no. 8, Aug. 1919, pp. 245-249.

Labrecque, Marie-France. "Développement du capitalisme dans la région de Weymontachie (Haute-Mauricie): incidence sur la condition des femmes attikamèques." Recherches Amérindiennes au Québec, vol. 14, no. 3, 1984, pp. 75-87.

Lanthier, Pierre, and Alain Gamelin. L'industrialisation de la Mauricie: Dossier statistique et chronologie, 1870-1975. Groupe de recherche sur la Mauricie, 1981.

Lefebvre, Olivier. "The St. Maurice river regulation and the Gouin dam." Journal of the Engineering Institute of Canada, vol. 3, no. 7, 20 July 1920, p. 343.

Léger, Yves. Occupation et utilisation du territoire par les Attikameks d'Obedjiwan. Rapport présenté au Conseil Attikamek-Montagnais, 1983.

Li, Tania Murray. The Will to Improve. Governmentality, Development, and the Practice of Politics. Duke UP, 2007. 
"Map of Power Plants on the Saint-Maurice River [diagram A]." Shawinigan Water and Power Company, The St. Maurice, a 2,000,000 h.p. river. Shawinigan Water and Power Company, 1942.

McDougall, Thomas. Letter to Simon-Napoléon Parent. 1912. F01/3289. Shawinigan Water and Power Company collection. Hydro-Québec Archives, Montreal, September 2012.

------. Letter to E.E. Taché. 5 Feb. 1912. F01/3292. Shawinigan Water and Power Company collection. Hydro-Québec Archives, Montreal, September 2012.

McNulty, Gerry, and Louis Gilbert. "Attikamek (Tête de Boule)." Handbook of North American Indians: Subarctic. Edited by June Helm, vol. 6, Smithsonian Institution, 1981, pp. 208-216.

Mercier, André. "Cimetière ancestral dévasté, les Atikamekws pointent du doigt Hydro-Québec." Le Nouvelliste, 9 June 2007, p. 3.

Ministère des Affaires Indiennes du Canada / Department of Indian Affairs (MAI). Rapport annuel. MAI, 1906.

Murphy, Alexander B. "Entente Territorial: Sack and Raffestin on Territoriality." Environment and Planning D: Society and Space, vol. 30, no. 1, 2012, pp. 159-172. https://doi.org/10.1068/d4911

Nehirowisiw Kitci Atisokan. "Tapiskwan sipi (la rivière Saint-Maurice)." Recherches amérindiennes au Québec, vol. 44, no. 1, 2014, pp. 85-93. https://doi.org/10.7202/1027882ar

Niosi, Jorge. "La Laurentide (1887-1928) : pionnière du papier journal au Canada." Revue d'histoire de l'Amérique française, vol. 29, no 3, 1975, pp. 375-415.

"Le Père Guinard nous parle des Indiens du St-Maurice." Le Nouvelliste (Trois-Rivières), 10 Aug. 1939, p. 10.

Poirier, Sylvie. "The Atikamekw. Reflections on their changing world." Native Peoples: The Canadian Experience, edited by Bruce Morisson and R. Wilson, Oxford UP, 2004, pp. 129-149.

Poirier, Sylvie. "Territories, Identity, and Modernity among the Atikamekw (Haut Saint-Maurice, Québec)." Aboriginal Autonomy and Development in Northern Quebec and Labrador, edited by C.H. Scott, UBC P, 2001, pp. 98-116.

Poirier, Sylvie. "Contemporanéités autochtones, territoires et (post) colonialisme : réflexions sur des exemples canadiens et aus- 
traliens." Anthropologie et Sociétés, vol. 24, no. 1, pp. 137-153. https://doi.org/10.7202/015640ar

Raffestin, Claude. "Territorialité: Concept ou Paradigme de la géographie sociale?" Geographica Helvetica, no. 2, 1986, pp. 91-96.

Sack, Robert. Human Territoriality: Its Theory and History. Cambridge UP, 1986.

Samson, Hubert. Les rapports de territorialités entre les Atikamekw et les allochtones en Haute-Mauricie, 1900-1930. 2014. Université du Québec à Trois-Rivières, MA thesis.

Sieyer, F. Engineering Report. 5 June 1907. F01/2661. Shawinigan Water and Power Company Collection. Hydro-Québec Archives, Montreal, September 2012.

Specific Claims Tribunal Canada (SCT). Atikamekw d'Opitciwan First Nation v. Her Majesty the Queen in Right of Canada, 2016. https://decisions.sct-trp.ca/sct/rod/en/item/181878/index.do

------. "Welcome to the Specific Claims Tribunal Canada." Specific Claims Tribunal Canada, Government of Canada, 2020. https://www.sct-trp.ca/hom/index_e.htm.

Taché, E.E. Letter to Thomas McDougall. 29 Nov. 1909. F01/3252. Shawinigan Water and Power Company Collection. HydroQuébec Archives, Montreal, September 2012. 
